\title{
Design and Analysis of LLC Resonant Converter for PV Energy Harvest
}

\author{
Neethumol A S, Anil Kumar V M \\ Department of Electrical and Electronics Engineering. Government Engineering College, Idukki, India \\ Department of Electrical and Electronics Engineering .Government Engineering College, Idukki, India
}

Abstract: Different types of converters are used for photovoltaic energy harvest. But the disadvantages are higher switching losses and they cannot maintain the efficiency for wide input range. In this paper a dual mode resonant converter is proposed. This converter can change the operating modes depending on photovoltaic panel operating condition. This converter achieves zero voltage switching for primary side switches and zero current switching for secondary diodes for both resonant modes. By reducing circulating energy the converter can maintain the high efficiency under wide input range under different output power levels.

IndexTerms: Resonant converter, photovoltaic system, zero voltage switching, zero current switching

\section{Introduction}

Energy consumption has been increasing in recent years and this fact has been essential to increase electric power generation. Renewable energy generations have drawn more and more attention in recent year. Among them, photovoltaic (PV) system has received a great attention as it appears to be one of the most promising renewable energy sources. Recently, due to its development and cost reduction, PV system becomes an efficient solution to the environmental problem.

The converters used for this application can be classified in to isolating and non isolating topologies. The non isolating topologies include boost, buck-boost, zeta, cuk and their derivatives. Isolated topologies mainly include flyback, current fed push-pull and resonant converters. Among these converters LLC converter is preferred due to its unique features like high efficiency soft-switching higher power density, high power application, wide input voltage range. LLC resonant converter cannot maintain high efficiency for a wide input range under different load conditions. In this paper, a new resonant $\mathrm{dc} / \mathrm{dc}$ converter with dual operation modes is proposed. By changing operation modes adaptively according to $V \mathrm{PV}$ and $P \mathrm{PV}$, the converter's efficiency is improved

Generally, MPPT is used for tracking the maximum power point in the PV system. The efficiency of MPPT depends on both the MPPT control algorithm and the MPPT circuit. The MPPT control algorithm is usually applied in the DC-DC converter, which is normally used as the MPPT circuit.

One of the most popular algorithms of MPPT is $\mathrm{P} \& \mathrm{O}$ (Perturb and Observe) technique. The main advantage of the $\mathrm{P} \& \mathrm{O}$ method is that it is easy to implement, it has low computational complexity and it is applicable for most of the PV systems. It does not require any information about the PV array except the measured voltage.

\section{Proposed Resonant Converter}

The proposed converter is shown in the circuit diagram. This consists of three switches. $\mathrm{S} 1$ and $\mathrm{S}_{2}$ are the two power MOSFETS. $\mathrm{D}_{\mathrm{s} 1}, \mathrm{C}_{\mathrm{s} 1}$ and $\mathrm{D}_{\mathrm{s} 2}, \mathrm{C}_{\mathrm{s} 2}$ are the body diodes and parasitic capacitances of $\mathrm{S}_{1}$ and $\mathrm{S}_{2}$ respectively. $\mathrm{Cr}$ is the resonant capacitor; $\mathrm{L}_{\mathrm{r}}$ and $\mathrm{L}_{\mathrm{m}}$ are the magnetizing inductance of transformers $\mathrm{T}_{\mathrm{x} 2}$ and $\mathrm{T}_{\mathrm{x} 1}$, respectively. $\mathrm{L}_{\mathrm{lkg}}$ is the sum of the leakage inductance of $\mathrm{T}_{\mathrm{x} 1}$ and $\mathrm{T}_{\mathrm{x} 2} \cdot \mathrm{D}_{1}, \mathrm{D}_{2}$ and $\mathrm{C}_{\mathrm{o} 1}, \mathrm{C}_{\mathrm{o} 2}$ form a voltage doubler at the secondary side of $T_{x 1}$. A half-wave rectifier (HWR) formed by $\mathrm{D}_{3}, \mathrm{~S}_{3}, \mathrm{D}_{4}$, and $\mathrm{C}_{\mathrm{O} 3}$ is added to the secondary side of transformer $\mathrm{T}_{\mathrm{x} 2}$. Diode $\mathrm{D}_{3}$ blocks the conductive path of the body diode of $\mathrm{S}_{3}$. Thus , $\mathrm{D}_{3}$ and $\mathrm{S}_{3}$ form a unidirectional switch to enable or disable the HWR

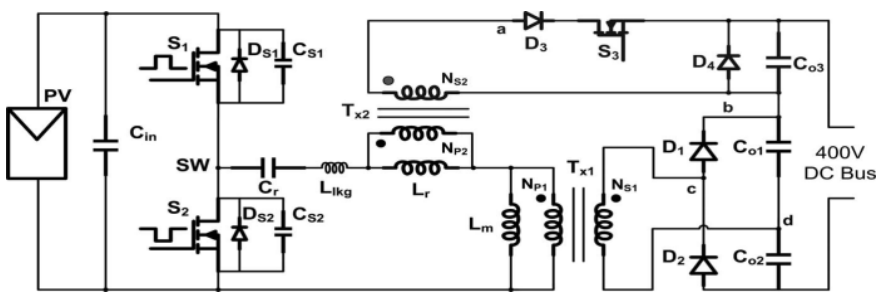

Fig.1.circuit Diagram of the proposed converter 
This converter has two operating modes. Depending on the panel operating condition the converter can change the resonant mode. In the first mode converter operates as traditional LLC resonant converter with voltage doubler by disabling the HWR. In the second mode HWR is enabled by turning on the switch $\mathrm{S}_{3}$. Table 1 summarizing the operating modes .for the first three condition converter operates in mode $I$. When $V_{p v}$ is smaller than $\mathrm{V}_{\text {th }}$ and $\mathrm{P}_{\mathrm{pv}}$ is lower than $50 \%$ of the rated power. The converters operate in mode II.

TABLE II: Operation modes for the proposed converter

\begin{tabular}{|l|l|}
\hline PV Operation Condition & Operation Modes \\
\hline \#1Vpv $>$ Vth; Ppv $>$ Pth & Mode $1 ;$ HWR Disabled \\
\hline$\# 2$ Vpv $>$ Vth; Ppv $<$ Pth & Mode $1 ;$ HWR Disabled \\
\hline$\# 3$ Vpv $<$ Vth; Ppv $>$ Pth & Mode $1 ;$ HWR Disabled \\
\hline$\# 4 V p v<=$ Vth; Ppv $<=$ Pth & Mode $11 ;$ HWR Enabled \\
\hline
\end{tabular}

\section{II.Design Consideration}

The main equations for the design of the modified resonant converter are presented with an Example. Considering the following specification

Output power $=240 \mathrm{~W}$

Input Voltage $=22 \mathrm{~V}$ to $44 \mathrm{~V}(32 \mathrm{~V}$ nominal $)$

Output voltage $=200 \mathrm{~V}$

Transformer turns ratio

Design is started by calculating the transformer turn ratio and the minimum and maximum voltage gains of the resonant tank, as follows.

Converter gain $=$ switching bridge gain*resonant tank gain*

Transformer turn ratio $(\mathrm{Ns} / \mathrm{Np})$

Where the switching bridge gain is1for a Full-Bridge and 0.5 for a Half-Bridge. Here half bridge is used in the input side. So switching bridge gain is 0.5 and resonant tank gain is chosen as 1 .

Converter voltage gain $=400 / 32$

Transformer turns ratio $=(.5 * 1 * 32) / 200=.008$

$\mathrm{M} \max =\frac{\operatorname{Vin} \text { nom } * \text { Mnom }}{\operatorname{Vin} \min }=1.45$

$\mathrm{M} \max =\frac{\operatorname{Vin} \operatorname{nom} * \text { Mnom }}{\operatorname{Vin} \max }=.8$

Selecting the $\mathrm{Q}_{\max }$ Value

Quality factor $\mathrm{Q}=\frac{\sqrt{\frac{L r}{C r}}}{R a c}$, depends on the load current .Heavy load conditions operate at high $\mathrm{Q}$ values, while lighter loads have lower $\mathrm{Q}$ values .It is important to set a value for the $\mathrm{Q}_{\max }$ associated with the maximum load point. Here Q is selected as 0.3 .

Selecting the $m$ Value

$\mathrm{M}=(\mathrm{Lr}+\mathrm{Lm}) / \mathrm{Lr}$ is a static parameter. Lower values of $\mathrm{m}$ can achieve higher boost gain. More flexible control and regulation which is valuable in applications with wide input voltage range Nevertheless, low values Of $\mathrm{m}$ for the same quality factor $\mathrm{Q}$ and resonant frequency Fr means small magnetizing inductance Lm, hence, higher magnetizing peak-peak current ripple, causing increased circulating energy and conduction losses. Here $\mathrm{m}$ is chosen as 6.3

Calculating Resonant Components Values

Resonant components are designed using the following equations

$\operatorname{Rac}=\frac{8 * V o^{2} N p^{2}}{\pi^{2} N s^{2} \text { Pomax }^{2}}=0.86$

$\mathrm{Q}=\frac{\sqrt{\frac{L r}{C r}}}{R a c}$ 


$$
\begin{aligned}
\mathrm{Fr}=\frac{1}{2 * \pi \sqrt{L * C}} \quad \mathrm{Fr}=20 \mathrm{kHz} \\
\mathrm{M}=(\mathrm{Lr}+\mathrm{Lm}) / \mathrm{Lr}
\end{aligned}
$$

Solving above equation the values of resonant components are

$$
\begin{aligned}
& \mathrm{Lr}=2 \mu \mathrm{H} \\
& \mathrm{Lm}=12 \mu \mathrm{H} \\
& \mathrm{Cr}=30 \mu \mathrm{F}
\end{aligned}
$$

A secondary winding is added to $L r$ such that it forms the transformer $T x 2$. The devices $D 3 D 4$, and $S 3$ in HWR have the same current rating as $D 1$ and $D 2$ in voltage doubler. Considering that a practical transformer has a certain leakage inductance, the value of $L \mathrm{lkg}$ can be chosen to be $5-15 \%$ of $(L r+L m)$.

\section{III.PV Modeling}

The model of solar cell can be categorized as p-n semiconductor junction; when exposed to light, the DC current is generated. The generated current depends on solar irradiance, temperature, and load current. The typical equivalent circuit of PV cell is shown in Fig. 2.

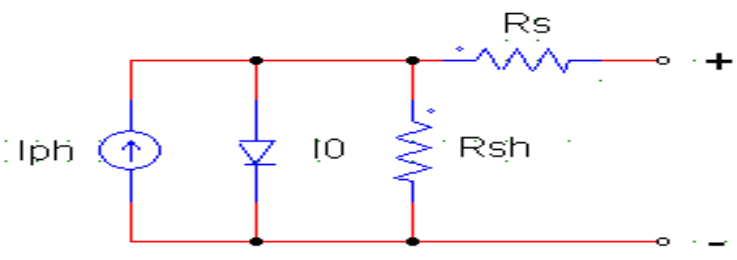

Fig 2.Equivalent circuit of solar cell

The current generated in cells by the solar irradiation, Iph, depends of the Isc, the short-circuit current, Ki, the short-circuit current temperature coefficient and the $\mathrm{Tr}$, reference temperature.

$$
I s c+K i(T-T r) K / 1000
$$

The saturation current I0 varies with the cell temperature and can be modulated by the ideality factor A. Eg0 is the band gap for silicon and his value is $1.1 \mathrm{eV}, \mathrm{q}$ is electron charge $(1.6 \times 10-19 \mathrm{C})$ and $\mathrm{k}$ is the Boltzmann constant (1.3805 x 10-23 J/K).

$$
\mathrm{Io}=\operatorname{IrS} *\left(\frac{T}{\text { Tref }}\right)^{3} \exp \left(\frac{q E g o}{A K}\left(\frac{1}{\operatorname{Tr}}-\frac{1}{T}\right)\right)
$$

A number of cells are connected together so as to form the PV modules. The mathematical model of PV system is described by following equations

$$
\mathrm{I}=\mathrm{np} * \mathrm{Iph}-\mathrm{np} * \operatorname{Io}\left[\exp \left(\frac{q V}{k T A n s}\right)-1\right]
$$

In this equation, Iph is the photocurrent, Io is the reverse saturation current of the diode, $\mathrm{q}$ is the electron charge, $\mathrm{V}$ is the voltage across the diode, $\mathrm{K}$ is the Boltzmann's constant, $\mathrm{T}$ is the junction temperature, $\mathrm{A}$ is the ideality factor of the diode, and ns number of cells connected in series.np is the number of solar cells connected in parallel

\section{Simulation Result}

To evaluate the performance of the proposed converter, the circuit is designed and simulation model was developed in PSIM. POWERSIM (PSIM) is fast simulation software used at circuit level or system level with a friendly user interface It is especially used in simulation of power converters and control circuits. The PSIM simulation package consists of three programs: circuit schematic editor SIMCAD, PSIM simulator, and waveform processing program SIMVIEW.

The PSIM model of the proposed converter is shown in figure. The input output voltage waveform also shown. The Simulation studies were carried out for an input voltage of 22 to $44 \mathrm{~V}$. The output voltage is of $400 \mathrm{~V}$. The switching frequency is of $20 \mathrm{kHz}$.

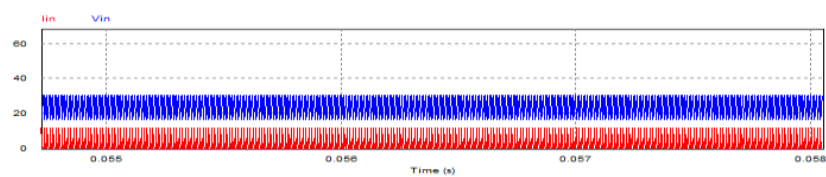


Fig.3.Input voltage and current waveforms

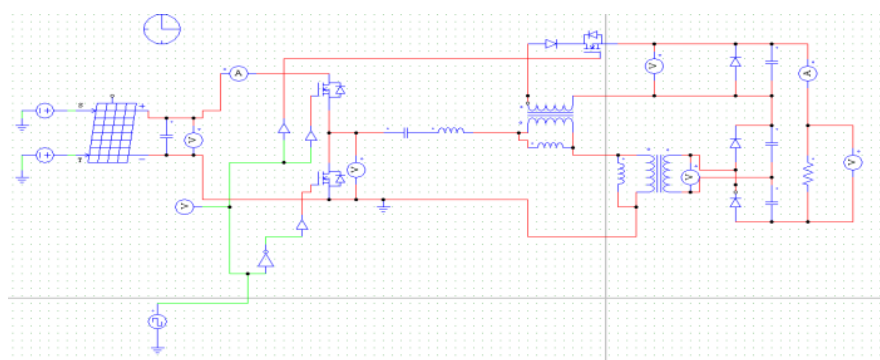

Fig.4.simulation setup of proposed converter
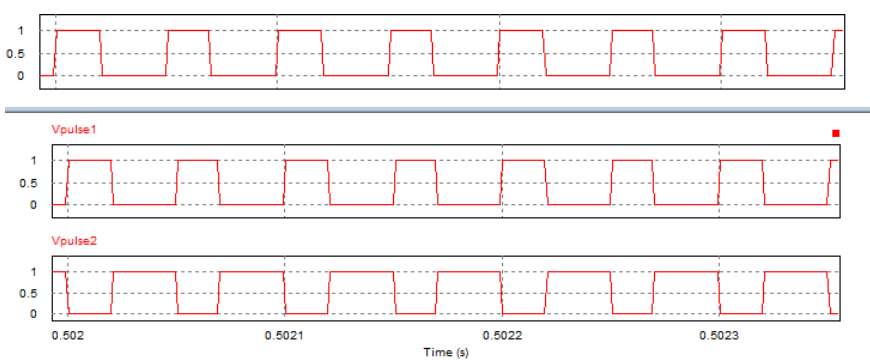

Fig.5.Gate pulses to switches

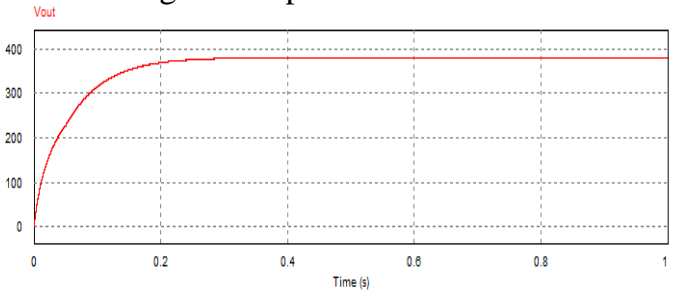

Fig.5.Output voltage waveform

\section{Conclusion}

The new resonant converter can change resonant modes adaptively depending on the PV panel operation conditions.

The converter achieves zero-voltage switching for primary side Switches and zero-current switching for secondary-side diodes for both resonant modes. The circulation energy is minimized particularly for $5-50 \%$ of the rated power level. Thus, the converter can maintain a high efficiency for a wide input range at different output power levels.

\section{References}

[1]. Application Notes, "Half-bridge LLC resonant converter design using FSFR-series Fairchild Power Switch (FPS)," Application Note AN4151 (2007). [Online]. Available: http://www.fairchildsemi.com/ AN- 4151.pdf

[2]. J. F. Lazar and R. Martinelli, "Steady-state analysis of the LLC series resonant converter," in Proc. IEEE 16th Annu. Conf. Appl. Power Electron.Conf. Expo. (APEC), Anaheim, CA, Mar. 2001, pp. 728-735.

[3]. G. R. Walker and P. C. Sernia, "Cascaded DC-DC converter connection of photovoltaic modules," IEEE Trans. Power Electron., vol. 19, no. 4, pp. 1130-1139, Jul. 2004.

[4]. Y. Gu, L. Hang, Z. Lu, Z. Qian, and D. Xu, "Voltage doubler applicationin isolated resonant converters," in Proc. IEEE 31st Annu. Conf. Ind.Electron. Soc. (IECON), Nov. 2005, pp. 1184-1188.

[5]. B. Lu et al., "Optimal design methodology for LLC resonant converter," in Proc. IEEE 21st Appl. Power Electron. Conf. Expo. (APEC-06), pp. 19-23.

[6]. S. De Simone, C. Adragna, C. Spini, and G. Gattavari, "Design-oriented steady-state analysis of LLC resonant converters based on FHA," in Proc.Int. Symp. Power Electron.,Electr. Drives, Autom. Motion (SPEEDAM),2006, pp. 16-23. 